\title{
Yield and Yield Attributes of Garden Pea (Pisum sativum var. hortense L.) as Influenced by Nutrient Management Practices under Agroclimatic Conditions of Meghalaya
}

\author{
M. Bilashini Devi*, M. Thoithoi Devi, A. K. Jha, Anjoo Yumnam, A. Balusamy, \\ V.K. Verma, H.D. Talang, N.A. Deshmukh, H. Rymbai and S.R. Assumi \\ ICAR Research Complex for NEH Region, Umiam-793103, Meghalaya, India \\ *Corresponding author
}

A B S T R A C T

\section{Keywords \\ Boron, Nutrient \\ Management Practice, \\ Pisum sativum, Pod yield, \\ Rock Phosphate \\ Article Info \\ Accepted: \\ 24 August 2018 \\ Available Online: \\ 10 September 2018}

The present investigation was undertaken with the main objective of studying the influence of nutrient management practices on yield and yield attributes of garden pea varieties viz., Vivek Matar-11 and VivekMatar-12 during rabi season, 2017. The experiment consisted of seven nutrient management practices replicated thrice in factorial RBD. The results revealed that the tallest plant $(99.74 \mathrm{~cm})$, significantly early flowering (89.83 days), maximum number of pods per plant (16.67), number of seeds per pod (7.33) and pod yield (9.63 t/ha) was recorded in Vivek Matar-12 with $50 \%$ recommended dose of $\mathrm{N}$ through urea $+50 \%$ recommended dose of $\mathrm{N}$ through FYM + recommended dose of PK through single super phosphate (SSP) and muriate of potash $(\mathrm{MOP})+0.2 \% \mathrm{~B}$. The same treatment combination also recorded second highest $\mathrm{B}$ : $\mathrm{C}$ ratio in both the evaluated varieties.

\section{Introduction}

Garden Pea (Pisum sativum var. hortense L.) is one of the most important vegetable crops belonging to the family Leguminaceae.

It is the second most important legume crop of the world (Pawar et al., 2017). The green and dry foliage are used as cattle feed and green pods being highly nutritious are preferred for culinary purpose. This legume contain high percentage of digestible protein $(7.2 \mathrm{~g})$, carbohydrates (15.8 g), vitamin A (139 I.U.), vitamin $\mathrm{C}(9 \mathrm{mg})$, magnesium $(34 \mathrm{mg}$ ) and phosphorus $(139 \mathrm{mg})$ per $100 \mathrm{~g}$ of edible portion (Gopalan, 2007).
Garden pea has long been recognized as a restorer of soil fertility due to their unique ability of symbiotic nitrogen fixation (Rana $e t$ al., 1998). This ability has made the crop as one of the most important and useful component of existing cropping system in the present context of soil fertility degradation. Improving the yield of garden pea depends on proper nutrient management and genetic makeup of the variety. Fertilizers play an important role on growth and productivity of garden pea. Nitrogen is essential for synthesis of chlorophyll, enzymes and protein. Phosphorus is essential for root growth, nodulation, energy storage and transfer necessary for metabolic processes. Potassium 
plays an important role in the promotion of enzyme activity and enhancing the translocation of assimilates and protein synthesis (Zaghlou et al., 2015). But the imbalance and improper use of chemical fertilizers has adverse effect on soil health thereby affecting the yield and sustainability of production, besides causing environmental pollution. Therefore, there is a need for judicious use of fertilizers for sustainable production and better soil health. This will help to sustain crop yield, improve the physical, chemical and biological properties of soil, and increase the efficiency of applied fertilizers (Singh and Biswas, 2000).

Super phosphate fertilizers have been widely used to improve crop production. Due to high cost of superphosphate, focus is now on rock phosphate as a source of natural phosphorus (P) because of its relatively low cost and soil of the region being acidic, makes the $\mathrm{P}$ from rock phosphate also available. In respect of using micronutrients, Sarkar et al., (2007) reported that the use of micronutrients in garden pea significantly increased the yield of agricultural crops. Boron (B) is one of the essential micronutrient required for normal growth of the plants and plays a vital role in promoting growth, yield and nodulation in garden pea. So, the current study includes rock phosphate and B as source of nutrients to evaluate its influence on growth, yield attributes and yield of garden pea.

\section{Materials and Methods}

The experiment was conducted at the Horticulture Experimental Farm, ICAR Research Complex for NEH Region, Umiam, Meghalaya. The experiment was laid out in Factorial Randomized Block Design with 14 treatment combinations replicated thrice during rabi season, 2017. The experimental site is situated at an elevation of $950 \mathrm{~m}$ above the mean sea level (MSL) with $25^{\circ} 41^{\prime} \mathrm{N}$ latitude and $91^{\circ} 54^{\prime} \mathrm{E}$ longitude. The location is characterized by subtropical climate and received an average annual rainfall of 150-250 $\mathrm{cm}$ with $80 \%$ of the rainfall occurring during the period from April to September. The available NPK and B of the experimental farm is $134 \mathrm{mg}$; $9.8 \mathrm{mg} ; 69.2 \mathrm{mg}$ and $0.26 \mathrm{mg}$ per $\mathrm{Kg}$ soil, respectively. The treatment detail is as follows:

\section{Variety}

$\mathrm{V}_{1}$ - Vivek Matar-11

$\mathrm{V}_{2}-$ Vivek Matar-12

\section{Nutrient management}

$\mathrm{T}_{1}-$ Control

$\mathrm{T}_{2}-\mathrm{RDF}$ (20:60:40 kg/ha NPK through urea, SSP and MOP)

$\mathrm{T}_{3}-\mathrm{RDF}$ of $\mathrm{N}$ through FYM

$\mathrm{T}_{4}-50 \% \mathrm{RDF}$ of $\mathrm{N}$ through urea $+50 \%$ recommended dose of $\mathrm{N}$ through $\mathrm{FYM}+$ recommended dose of PK through SSP and $\mathrm{MOP}+0.2 \% \mathrm{~B}$

$\mathrm{T}_{5}$ - RDF of NPK through urea, rock phosphate and muriate of potash

$\mathrm{T}_{6}-\mathrm{RDF}$ of NK through urea and MOP + double the dose of recommended $\mathrm{P}$ from SSP

$\mathrm{T}_{7}-\mathrm{RDF}$ of $\mathrm{N}$ and $\mathrm{K}$ through urea and $\mathrm{MOP}+$ double the dose of recommended $\mathrm{P}$ from rock phosphate

$0.2 \% \mathrm{~B}$ was sprayed as per the treatment detail at the time of flower initiation by using knapsack sprayer. To raise the crop recommended package of practices were followed. The treatments were evaluated on the basis of growth, flowering and yield performance. The mean data were subjected to 
statistical analysis following analysis of variance technique (Gomez and Gomez, 1984).

\section{Results and Discussion}

Different nutrient management practices influenced growth parameters viz., plant height, number of primary branches per plant, days taken to $50 \%$ flowering as well as

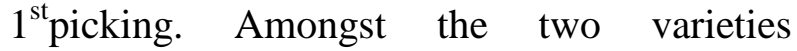
evaluated, Vivek Matar-12 showed significantly taller plant $(99.74 \mathrm{~cm})$, maximum number of primary branches per plant (2.21) and minimum days taken to $50 \%$ flowering (89.83 days) and $1^{\text {st }}$ picking (129 days). Application of $50 \%$ recommended dose of $\mathrm{N}$ through urea $+50 \%$ recommended dose of $\mathrm{N}$ through FYM + recommended dose of PK through SSP and MOP $+0.2 \% \mathrm{~B}$ showed significantly taller plant, maximum number of primary branches per plant and minimum days taken to $50 \%$ flowering and $1^{\text {st }}$ picking in both the varieties under study. While minimum plant height, lowest number of primary branches per plant and maximum days to 50\% flowering and $1^{\text {st }}$ picking was recorded in control. The increase in growth parameters under this treatment might be due to adequate availability of macro and micro nutrients and improved soil health due to incorporation of organic manure. The application of organic manure also facilitates greater availability and continuous supply of plant nutrients for longer period and thus provides a better environment for root growth and proliferation.

Besides, application of boron enhanced the photosynthetic activity, resulting in increased production and accumulation of carbohydrates which in turn favorably affect the plant growth. These findings are in consonant with the findings of Jaipaul et al., (2011), Sharma et al., (2011), Sharma and Chauhan (2011), Dubey et al., (2012) and Kumari et al., (2012) in garden pea.
Amongst the genotypes, Vivek Matar-12 recorded significantly higher number of pods per plant (16.67), higher pod length $(7.22 \mathrm{~cm})$, higher number of seeds per pod (7.33) and higher pod yield (9.63 t/ha) over Vivek Matar11. The increase in growth components and pod yield of Vivek Matar-12 may be attributed to genetic makeup of the variety. Afreen et al., (2017) also reported varietal differences for growth components and pod yield in garden pea.

The interaction effect of nutrient management practices and varieties was found to be significant for all the traits under study except for pod length, number of pods per plant and number of primary branches per plant. This indicates that interaction between fertilizers and varieties significantly affected most of the traits under study.

The increase in pod yield with application of $50 \%$ recommended dose of $\mathrm{N}$ through urea + $50 \%$ recommended dose of $\mathrm{N}$ through FYM + recommended dose of PK through SSP and $\mathrm{MOP}+0.2 \% \mathrm{~B}$ may be attributed to better growth in terms of plant height and number of primary branches, which reflected into improved yield components viz., number of pods per plant, pod length and pod yield per plant as compared to other treatments.

In the early growth phase, the immediate requirements of nutrients were fulfilled through nutrients released from fertilizers while in later stage of plant development, the required nutrients are provided through decomposition of organic manures. Boron as micronutrient supplement in the treatment combination might have also increased the plant's use efficiency of macronutrients (NPK) due to their improved recovery efficiency by plant (Manoj et al., 2016). The findings are in close conformity with those of Sepehya et al., (2012), Singh et al., (2014) and Pawar et al., (2017) in garden pea (Table 1-5). 
Table.1 Effect of nutrient management on $50 \%$ flowering and $1^{\text {st }}$ picking

\begin{tabular}{|c|c|c|c|c|c|c|}
\hline Treatment & \multicolumn{3}{|c|}{ Days to $50 \%$ Flowering } & \multicolumn{3}{|c|}{ Days to First Picking } \\
\hline & $\mathbf{V}_{1}$ & $\mathbf{V}_{2}$ & Mean & $\mathbf{V}_{1}$ & $\mathbf{V}_{2}$ & Mean \\
\hline $\mathbf{T}_{1}$ & 109.00 & 106.08 & 107.54 & 145.20 & 145.30 & 145.25 \\
\hline $\mathbf{T}_{2}$ & 103.87 & 102.00 & 102.93 & 141.51 & 144.41 & 142.96 \\
\hline $\mathbf{T}_{\mathbf{3}}$ & 111.00 & 93.13 & 102.07 & 140.67 & 138.50 & 139.59 \\
\hline$\overline{\mathbf{T}_{4}}$ & 102.31 & 89.83 & 96.07 & 139.00 & 129.00 & 134.00 \\
\hline $\mathbf{T}_{5}$ & 106.67 & 96.00 & 101.33 & 141.00 & 137.67 & 138.33 \\
\hline $\mathrm{T}_{6}$ & 103.74 & 93.20 & 98.47 & 142.08 & 139.00 & 140.54 \\
\hline$\overline{\mathbf{T}_{7}}$ & 106.33 & 104.00 & 105.17 & 142.81 & 144.00 & 143.41 \\
\hline & 106.13 & 97.75 & & 141.75 & 139.70 & \\
\hline & S.Em \pm & CD at $5 \%$ & & S.Em \pm & CD at $5 \%$ & \\
\hline $\begin{array}{l}\text { Variety } \\
\text { (V) }\end{array}$ & 0.54 & 1.57 & & 0.35 & 1.01 & \\
\hline $\begin{array}{l}\text { Treatment } \\
\text { (T) }\end{array}$ & 1.00 & 2.93 & & 0.65 & 1.89 & \\
\hline $\begin{array}{l}\text { Interaction } \\
(\mathbf{V} \times \mathbf{T})\end{array}$ & 1.42 & 4.15 & & 0.91 & 2.67 & \\
\hline
\end{tabular}

Table.2 Effect of nutrient management on pod length and no. of seeds per pod

\begin{tabular}{|c|c|c|c|c|c|c|}
\hline Treatment & \multicolumn{3}{|c|}{ Pod length (cm) } & \multicolumn{3}{|c|}{ No. of seeds per pod } \\
\hline & $\mathbf{V}_{1}$ & $\mathbf{V}_{2}$ & Mean & $\mathbf{V}_{1}$ & $\mathbf{V}_{2}$ & Mean \\
\hline$\overline{T_{1}}$ & 5.69 & 6.02 & 5.86 & 5.10 & 4.24 & 4.67 \\
\hline$\overline{\mathbf{T}_{2}}$ & 6.40 & 6.58 & 6.49 & 5.74 & 5.89 & 5.81 \\
\hline$\overline{T_{3}}$ & 6.00 & 6.90 & 6.45 & 5.18 & 6.41 & 5.80 \\
\hline$\overline{\mathbf{T}_{4}}$ & 6.77 & 7.22 & 7.00 & 6.39 & 7.33 & 6.86 \\
\hline $\mathbf{T}_{5}$ & 6.15 & 7.19 & 6.67 & 6.37 & 7.21 & 6.79 \\
\hline $\mathrm{T}_{6}$ & 6.71 & 6.95 & 6.83 & 6.07 & 6.67 & 6.37 \\
\hline$\overline{T_{7}}$ & 6.72 & 7.14 & 6.93 & 6.37 & 7.05 & 6.71 \\
\hline & 6.35 & 6.86 & & 5.89 & 6.40 & \\
\hline & S.Em \pm & CD at $5 \%$ & & S.Em \pm & CD at $5 \%$ & \\
\hline Variety (V) & 0.11 & 0.30 & & 0.05 & 0.16 & \\
\hline Treatment (T) & 0.19 & 0.57 & & 0.10 & 0.29 & \\
\hline $\begin{array}{l}\text { Interaction }(\mathrm{V} \times \\
\mathrm{T})\end{array}$ & 0.27 & NS & & 0.14 & 0.42 & \\
\hline
\end{tabular}


Table.3 Effect of nutrient management on no. of pods per plant and pod yield

\begin{tabular}{|c|c|c|c|c|c|c|}
\hline Treatment & \multicolumn{3}{|c|}{ No. of pods per plant } & \multicolumn{3}{|c|}{ Yield (q/ha) } \\
\hline & $\mathbf{V}_{1}$ & $\mathbf{V}_{2}$ & Mean & $V_{1}$ & $\mathbf{V}_{2}$ & Mean \\
\hline $\mathbf{T}_{1}$ & 11.67 & 11.00 & 11.33 & 50.39 & 53.52 & 51.96 \\
\hline $\mathbf{T}_{2}$ & 13.33 & 13.33 & 13.33 & 66.08 & 66.53 & 66.31 \\
\hline $\mathbf{T}_{3}$ & 12.00 & 15.00 & 13.50 & 55.03 & 75.67 & 65.35 \\
\hline $\mathbf{T}_{4}$ & 14.67 & 16.07 & 15.67 & 74.53 & 96.29 & 85.41 \\
\hline $\mathbf{T}_{5}$ & 12.67 & 16.67 & 14.67 & 61.05 & 93.57 & 77.31 \\
\hline$T_{6}$ & 13.33 & 15.00 & 14.17 & 68.01 & 88.55 & 75.78 \\
\hline $\mathbf{T}_{7}$ & 14.33 & 15.33 & 14.83 & 71.56 & 84.06 & 77.81 \\
\hline & 13.14 & 14.71 & & 63.81 & 79.03 & \\
\hline & S.Em \pm & CD at $5 \%$ & & S.Em \pm & CD at $5 \%$ & \\
\hline Variety $(\mathbf{V})$ & 0.43 & 1.25 & & 0.75 & 2.18 & \\
\hline $\begin{array}{l}\text { Treatment } \\
\text { (T) }\end{array}$ & 0.80 & 2.34 & & 1.39 & 4.07 & \\
\hline $\begin{array}{l}\text { Interaction } \\
(\mathrm{V} \times \mathrm{T})\end{array}$ & 1.13 & NS & & 1.97 & 5.76 & \\
\hline
\end{tabular}

Table.4 Effect of nutrient management on shelling \% and plant height

\begin{tabular}{|c|c|c|c|c|c|c|}
\hline \multirow[t]{2}{*}{ Treatment } & \multicolumn{3}{|c|}{ Shelling \% } & \multicolumn{3}{|c|}{ Plant Height (cm) } \\
\hline & $V_{1}$ & $\mathbf{V}_{2}$ & Mean & $V_{1}$ & $\mathbf{V}_{2}$ & Mean \\
\hline$\overline{T_{1}}$ & 44.83 & 44.22 & 44.53 & 44.79 & 40.24 & 42.52 \\
\hline $\mathbf{T}_{2}$ & 65.43 & 46.13 & 55.78 & 48.30 & 51.85 & 50.08 \\
\hline $\mathbf{T}_{3}$ & 58.22 & 55.66 & 56.94 & 47.69 & 41.24 & 44.47 \\
\hline$\overline{T_{4}}$ & 50.68 & 41.62 & 46.15 & 89.39 & 99.74 & 94.57 \\
\hline$T_{5}$ & 50.46 & 40.89 & 45.68 & 52.56 & 49.22 & 50.89 \\
\hline$T_{6}$ & 53.91 & 40.80 & 47.40 & 61.58 & 50.66 & 56.12 \\
\hline \multirow[t]{3}{*}{$\mathbf{T}_{7}$} & 38.09 & 58.05 & 48.07 & 76.16 & 48.85 & 62.51 \\
\hline & 51.66 & 46.78 & & 60.07 & 54.54 & \\
\hline & S.Em \pm & CD at $5 \%$ & & S.Em \pm & CD at $5 \%$ & \\
\hline $\begin{array}{l}\text { Variety } \\
\text { (V) }\end{array}$ & 0.71 & 2.06 & & 0.63 & 1.84 & \\
\hline $\begin{array}{l}\text { Treatment } \\
\text { (T) }\end{array}$ & 1.32 & 3.86 & & 1.18 & 3.45 & \\
\hline $\begin{array}{l}\text { Interaction } \\
(\mathrm{V} \times \mathrm{T})\end{array}$ & 1.87 & 5.45 & & 1.67 & 4.87 & \\
\hline
\end{tabular}


Table.5 Effect of nutrient management on primary branch per plant and TSS

\begin{tabular}{|c|c|c|c|c|c|c|}
\hline \multirow[t]{2}{*}{ Treatment } & \multicolumn{3}{|c|}{ Primary branch per plant } & \multicolumn{3}{|c|}{ TSS ( ${ }^{0}$ Brix $)$} \\
\hline & $V_{1}$ & $\mathbf{V}_{2}$ & Mean & $V_{1}$ & $\mathbf{V}_{2}$ & Mean \\
\hline $\mathbf{T}_{1}$ & 1.56 & 1.50 & 1.53 & 11.51 & 11.31 & 11.31 \\
\hline $\mathbf{T}_{2}$ & 2.13 & 1.77 & 1.95 & 19.72 & 19.95 & 19.84 \\
\hline $\mathbf{T}_{3}$ & 1.77 & 1.70 & 1.74 & 10.51 & 12.49 & 11.50 \\
\hline$\overline{T_{4}}$ & 2.00 & 2.21 & 2.11 & 11.78 & 17.33 & 14.56 \\
\hline $\mathbf{T}_{5}$ & 1.83 & 1.65 & 1.74 & 16.08 & 11.95 & 14.02 \\
\hline$T_{6}$ & 1.82 & 1.62 & 1.72 & 16.57 & 16.80 & 16.69 \\
\hline \multirow[t]{3}{*}{$\mathbf{T}_{7}$} & 1.57 & 1.82 & 1.70 & 11.02 & 11.63 & 11.32 \\
\hline & 1.81 & 1.75 & & 13.88 & 14.47 & \\
\hline & S.Em \pm & CD at $5 \%$ & & S.Em \pm & CD at $5 \%$ & \\
\hline $\begin{array}{l}\text { Variety } \\
\text { (V) }\end{array}$ & 0.13 & NS & & 0.50 & NS & \\
\hline $\begin{array}{l}\text { Treatment } \\
\text { (T) }\end{array}$ & 0.24 & NS & & 0.94 & 2.74 & \\
\hline $\begin{array}{l}\text { Interaction } \\
(\mathrm{V} \times \mathrm{T})\end{array}$ & 0.33 & NS & & 1.33 & 3.87 & \\
\hline
\end{tabular}

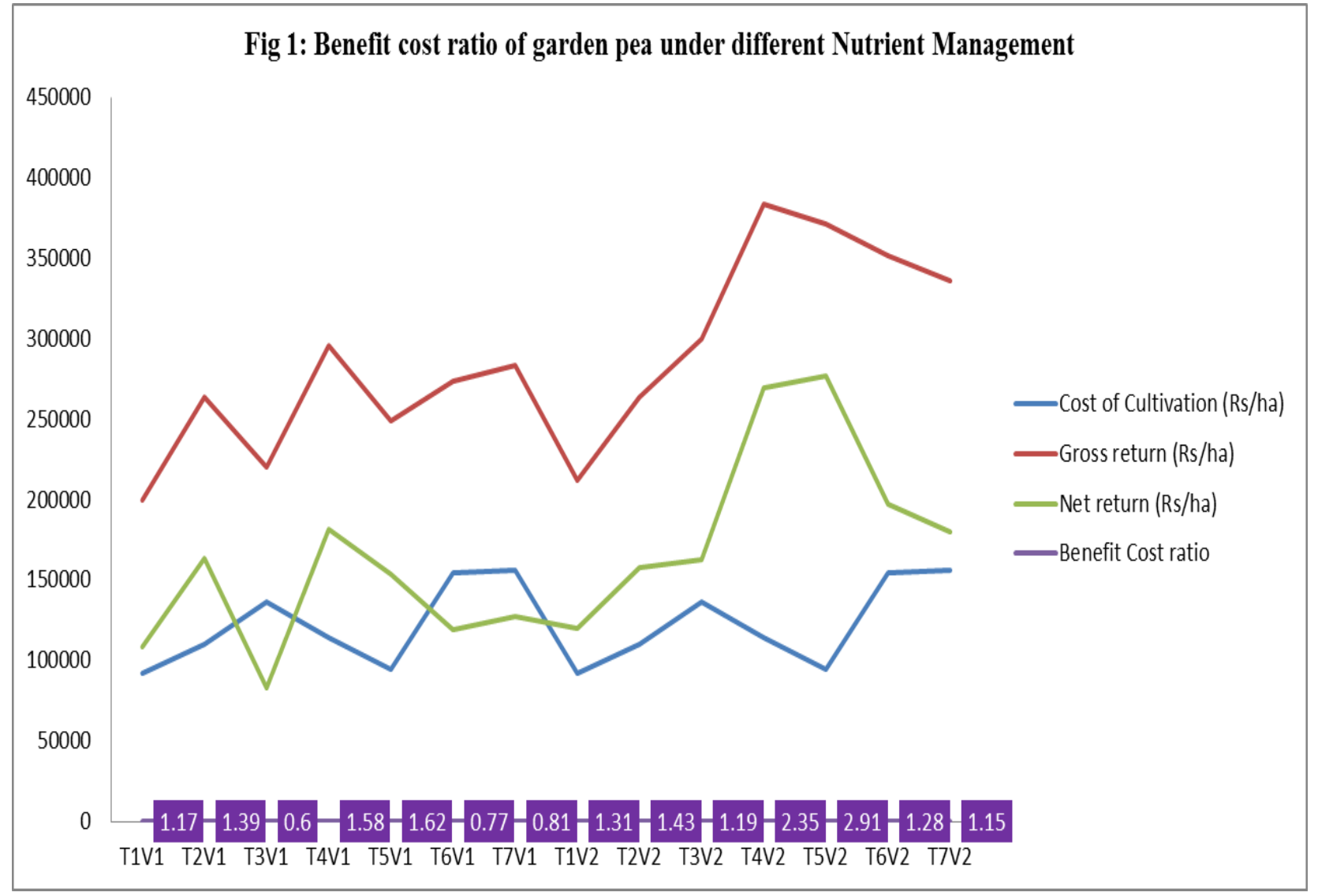


From the present study it is observed that higher dose of rock phosphate when applied along with the recommended dose of $\mathrm{N}$ and $\mathrm{K}$ gave good performance in terms of growth parameters and pod yield in both the evaluated varieties. This might have resulted from the higher availability of $\mathrm{P}$ due to better mineralization of nutrients. This better availability and uptake of $P$ increased growth parameters and hence pod yield. These results are inconformity with the findings of Shaktawat et al., (2006) who also reported that, higher phosphorus dose through rock phosphate either alone or in combination with acidulants give better result than the lower one.

\section{Benefit cost ratio}

The B: $\mathrm{C}$ ratio was observed to be greater than 1 (one) in all the treatment combinations for $\mathrm{V}_{2}$ (VivekMatar 12), implying that all the treatments were economically viable.

In case of $\mathrm{V}_{1}$ (VivekMatar 11 ), the $\mathrm{B}$ : $\mathrm{C}$ ratio was higher than 1 (one) in all treatment combinations except for treatments, $\mathrm{T}_{3}, \mathrm{~T}_{6}$ and $\mathrm{T}_{7}$. This observation was due to higher cost of productions in the treatment combinations incurred due to high dose of FYM in $\mathrm{T}_{3}$ and double doses of $\mathrm{P}$ in $\mathrm{T}_{6}$ and $\mathrm{T}_{7}$. Maximum $\mathrm{B}$ : $\mathrm{C}$ ratio in both the varieties was observed in case of nutrient management practice comprising of recommended dose of NPK through urea, rock phosphate and muriate of potash (Fig. 1). This was due to the lower cost of production owing to cheaper rate of rock phosphate as compared to SSP used in other treatment combinations. The second highest $\mathrm{B}$ : $\mathrm{C}$ ratio in both the varieties was observed in the nutrient management practice comprising of $50 \%$ recommended dose of $\mathrm{N}$ through urea $+50 \%$ recommended dose of $\mathrm{N}$ through FYM + recommended dose of PK through SSP and $\mathrm{MOP}+0.2 \% \mathrm{~B}$ which also recorded highest pod yield per hectare.

The treatments that combined 50\% recommended dose of $\mathrm{N}$ through urea $+50 \%$ recommended dose of $\mathrm{N}$ through $\mathrm{FYM}+$ recommended dose of PK through SSP and
$\mathrm{MOP}+0.2 \% \mathrm{~B}$ gave the best results in terms of all growth parameters measured as well as the pod yield, while the control showed the lowest values. This indicates that provided that the problem of affordability and procurement of chemical fertilizer by resource poor farmers persists, the use of this chemical fertilizer with organic source of nutrient (less expensive and affordable) would serve as a viable alternative. Considering both the fresh pod yield and B: C ratio, it can be concluded that reduced dose of chemical fertilizers upto50\% with incorporation of organic and micronutrient (Boron) gave highest yield and higher $\mathrm{B}$ : $\mathrm{C}$ ratio as compared to sole use of inorganic fertilizers. Further the conjoint application of rock phosphate as a source of phosphorus along with recommended dose of $\mathrm{N}$ and $\mathrm{K}$ can potentially benefit the farmers as it was economically more viable and also gave reasonably high yield. The efficacy of rock phosphate as an organic source of fertilizer needs to be further evaluated and studied.

\section{References}

Afreen, S., Singh A.K., Moharana, D.P., Singh V, Singh, P. and Singh, B. 2017. Genetic evaluation for yield and yield attributes in garden pea (Pisum sativum var. hortense L.) under North Indian Gangetic Plain conditions. International Journal of Current Microbiology and Applied Science. 6(2): 1399-1404

Dubey, D.K., Singh, S.S., Verma, R.S. and Singh, P.K. 2012. Integrated nutrient management in garden pea (Pisum sativum var. hortense). Hort. Flora Research Spectrum. 1:244-247.

Gomez, K.A., Gomez, A.A. 1984. Statistical procedures for agricultural research, 2nd edition. John Wiley and Sons, New York, pp.680.

Gopalan, C., Rama, S.B.V., Balasubramanian, S.C. 2007. Nutritive Value of Indian Foods- revised edition. National Institute of Nutrition, Indian Council of Medical Research, Hyderabad, India. P. 50.

Jaipaul, S., Dixit, A., Sharma, A.K. 2011. Growth and yield of capsicum (Capsicum 
annum) and garden pea (Pisum sativum) as influenced by organic manures and biofertilizers. Indian Journal of Agricultural Science.81:637-642.

Kumar, M., Jha, A.K., Hazarika, S., Verma, B.C., Choudhury, B.U., Ramesh, T., Moirangthem, P., Kumar, R., Brajendra, Rajkhowa, D.J., Kumar, A., and Devi, M.H. 2016. Micronutrients (B, Zn, Mo) for improving crop production on acidic soils of northeast India. National Academy Science Letter. 39(2):85-89

Kumari, A., Singh, O.N., Kumar, R. 2012.Effect of integrated nutrient management on growth, seed yield and economics of pea (Pisum sativum) and fertility changes. Journal of Food Legume. 25:121-124.

Pawar, Y., Varma, L.R., Verma, P., Joshi, H.N., More, S.G., Dabhi, J.S. 2017. Influences of integrated use of organic and inorganic sources of nutrients on growth, flowering and yield of garden pea (Pisum sativum L.) cv. Bonneville. Legume Research. 40 (1): 117-124

Rana, N.S., Singh, G.V. and Ahlawat, I.P.S. 1998. Effect of nitrogen, rhizobium inoculation and phosphorus on root nodulation, dry matter yield and nutrient uptake in pigeon pea (Cajanas cajan). Indian Journal of Agronomy. 43: 102106.

Sarkar, D., Mandal, B., Kundu, M.C. 2007. Increasing use efficiency of boron fertilizers by rescheduling the time and methods of application for crops in India. Plant Soil. 301:77-85.

Sepehya, S., Bhardwaj, S.K., Dixit, S.P. and Dhiman, S. 2012Effect of integrated nutrient management on yield attributes, yield and NPK uptake in garden pea (Pisum sativum L.) in acid Alfisol. Journal of Food Legume. 25:247-249.

Shaktawat, M. S., Sharma, D. D. and Mehta, Y. K. 2006. Rock phosphate applied along with acidulants under soybean mustard cropping system in alkaline soils. In: Phosphate Rich Organic Manure: An Alternate to Phosphate Fertilizers, Himanshu Publications. pp. 56-58.

Sharma, U., Chauhan, J.K. 2011.Influence of integrated use of inorganic and organic sources of nutrients on growth and production of pea. Journal of Farm Sciences. 1:14-18.

Sharma, V., Gupta, A., Khalsa, G.S. and Sharma, R. 2011.Direct and residual effect of integrated nutrient management on garden pea (Pisum sativum L.) based crop sequence in Lahaul Valley of Himachal Pradesh. Indian Journal of Agronomy. 56:351-355.

Singh, G.B., Biswas, P.P. 2000. Balanced and integrated nutrient management for sustainable crop production. Indian Journal of Fertilizers. 45: 55-60.

Singh, R.K., Singh, R.P., Choudhary, S.K. and Upadhyay, P.K. 2014. Effect of organic sources of nutrients on soil quality, productivity and economics of late sown chickpea and field pea. Green Farming. 5:796-800

Zaghlou, R.A., Abou, H.E., Rasha, M.E. and Mohamed, T.E. 2015. Improvement of growth and yield of pea plants using integrated fertilization management. Universal Journal of Agricultural Research. 3(4): 135-143

\section{How to cite this article:}

Bilashini Devi, M., M. Thoithoi Devi, A.K. Jha, Anjoo Yumnam, A. Balusamy, V.K. Verma, H.D. Talang, N.A. Deshmukh, H. Rymbai and Assumi, S.R. 2018. Yield and Yield Attributes of Garden Pea (Pisum sativum var. hortense L.) as Influenced by Nutrient Management Practices under Agroclimatic Conditions of Meghalaya. Int.J.Curr.Microbiol.App.Sci. 7(09): 3447-3454. doi: https://doi.org/10.20546/ijcmas.2018.709.427 